\title{
Interannual Variations of the Water Vapor Content and Its Flux Components over the Northern Hemisphere
}

\author{
By Mao-Fou Wu \\ Systems and Applied Sciences Corporation 6811 Kenilworth Avenue, Suite 610 \\ Riverdale, Maryland 20840, U.S.A. \\ (Manuscript received 27 December 1977, in revised form 12 October 1978)
}

\begin{abstract}
Five years of northern hemispheric data of specific humidity and winds have been analyzed on an annual basis to study the year to year changes in the field of the atmospheric water vapor. The major findings are: (1) the yearly mean total hemispheric precipitable water content of the atmosphere does not vary more than $4 \%$; (2) the zonally averaged E-W flux is comparatively stable, while the zonally averaged $\mathrm{N}-\mathrm{S}$ flux has interannual variations up to a factor of 2 in the magnitude of its maximum southward flow, and up to about $18 \%$ in the maximum northward transport; (3) with few exceptions, the locations of the large positive and negative centers in the maps of annual mean E-W and N-S flux components do not shift more than three degrees, but the magnitude of the center value does change substantially within the five-year period; and (4) the deviations of the water vapor content and its flux are affected by Tibetan Plateau, Rocky Mountains, monsoon activity and the year-to-year shift of the North Pacific high.
\end{abstract}

\section{Introduction}

There is at present considerable interest in the changes of climate. In order to investigate this long-term climatic trend, one has to know the natural variability of certain properties of atmosphere. Starr and Oort (1973) have studied the monthly mean temperature for the northern hemisphere for the period May 1958-April 1963; Oort (1974) has investigated the year-to-year variations in the energy balance of the Arctic atmosphere; Wu et al. (1974), and Gaut et al. (1976), on the other hand, have discussed the interannual changes in angular momentum and zonal kinetic energy of the atmosphere for the same five (5) year period. Since the atmospheric water vapor imposes a great deal of influence on the atmospheric energetics and climatic behavior, research on the atmospheric water vapor has been considered to be very important. The early studies of the hemispheric water vapor balance by Starr and White (1955), Starr et al. (1958), Starr and Peixoto (1958), and Starr et al. (1965) were based on data not exceeding one (1) year. With the increase of the aerological data Peixoto (1970) extended the analysis of the northern hemispheric humidity condition to cover the 5-year period 1958-1963. However, Peixoto's work dealt only with the 5-year mean values, and did not evaluate the year-to-year differences in the water vapor fields. Kubota (1971) investigated the seasonal variation in water vapor balance over the northern hemisphere based on Climatological data for 1958-1962, but again he did not show the year-to-year change. In view of current interest, the present paper seeks to focus upon the interannual variations in the water vapor content and its flux components. It is anticipated that the present work will be found useful to investigators engaged in studying the climate and the changes in the atmospheric circulation patterns.

\section{Symbols and formulae}

\subsection{Notation}

The following is a list of symbols which are used.

$$
\begin{aligned}
& \lambda=\text { longitude } \\
& \phi=\text { latitude }
\end{aligned}
$$


$p=$ pressure, $p_{0}$ denotes pressure at the surface

$(-)=\frac{1}{\tau} \int_{\tau}^{j}(\quad) d t$, bar denotes the time-average operator-here $\tau$ is one year

$u=$ zonal component of wind, positive eastward

$v=$ meridional component of wind, positive northward

$q=$ specific humidity

$g=$ acceleration of gravity

\subsection{Formulae}

$\overline{\mathrm{W}}=\frac{1}{g} \int_{p}^{p_{0}} \bar{q} d p=$ mean precipitable water vapor

$\bar{Q}_{\lambda}=\frac{1}{g} \int_{p}^{p_{0}} \overline{q u} d p=$ vertically integrated zonal flux of specific humidity

$\bar{Q}_{\psi}=\frac{1}{g} \int_{p}^{p_{0}} \bar{p} d p=$ vertically integrated meridfiux of specific humidity.

$D(\bar{X})=\sqrt{\frac{1}{5} \sum_{i=1}^{5}\left(\bar{X}_{i}-\overline{\bar{X}}\right)^{2}}=$ standard deviation of $\bar{X}$

$R(\bar{X})=[D(\bar{X}) / \overline{\bar{X}}] \times 100 \%=$ relative deviation of $\bar{X}$ $\overline{\bar{X}}=\frac{1}{5} \sum_{i=1}^{5}\left(\bar{X}_{i}\right)=$ five-year mean of $\bar{X}$

where $\bar{X}$ is any of the variables $\bar{W}, \bar{Q}_{\lambda}, \bar{Q}_{\phi}$.

\section{Data and analysis}

The data were obtained from the late Professor V.P. Starr of Massachusetts Institute of Technology. Through his diligent effort Starr has collected extensive data for the study of the general circulation over the northern hemisphere. This compilation has been named, "The MIT General Circulation Data Library." The period covered is from May 1, 1958 through April 30, 1963. (Starr et at. 1970). Since then many uses have been made of the Data Library. In recent years several investigators have evaluated the year-to-year variations of certain atmospheric properties as mentioned in Section 1. They define the "year" as running from May 1 of one calendar year through April 30 of the next in order to use all available data. In the present study, we utilize the 0000GMT observations of winds and humidity measured daily at about 800 stations located in the northern hemisphere. Some additional data gathered in the low latitudes of the southern hemisphere have also been included for improving the analysis of tropical regions. We adopt the same definition of the term "year" as defined by other investigators for the sake of convenience and consistency. Moreover, the period May 1, 1958 through April 30, 1959 will be referred to as Year 1, and so on for the following four (4) consecutive years.

The analysis scheme is this: The daily data of $q$ and the products of $q u$ and $q v$ were averaged first on a monthly basis and then on a yearly basis at each station and level thereof. The standard pressure levels used here range from surface to $300 \mathrm{mb}$ (about $9.1 \mathrm{~km}$ ), at intervals of $50 \mathrm{mb}$. The vertical integrals were evaluated by applying the trapezoidal rule. The results of vertical integration of $\bar{q}, \overline{q u}$, and $\overline{q v}$ at various meteorological stations were analyzed by machine to produce the horizontal maps. The zonal averaged values for various latitudinal belts were used as the initial guess field. The iterative interpolation technique, which satisfies Poisson's equation in finite difference form, was employed. Finally, the grid point values are obtained, and from which the zonal averages were computed.

It should be noted that each integrated quantity has been carefully checked before undergoing the horizontal analysis by the computer. In areas where observations were spare or missing, some appropriate values taking into account the readings from the humidity maps, prepared by Peixoto and Crisi (1965) for the year 1958, are inserted to the computer programs as the input data. Over such regions hand analysis was also performed for a comparison between the two schemes. It is noted that the difference is not serious, and that the results presented here are the outcome of machine.

\section{Results}

\subsection{1 $\bar{W}$-maps}

The annual mean precipitable water vapor content, $\bar{W}$, are presented in Figs. 1a-1e. Isolines were drawn for every $0.5 \mathrm{gm} \mathrm{cm}^{-2}$ by machine. Generally speaking, there is a continuous decrease of the water content from the equator to the pole. The field of $\bar{W}$ shows zonal asymmetry. The precipitable water is larger over the oceans than over the continents. Within the continent dry conditions (less than $2.0 \mathrm{gm} \mathrm{cm}^{-2}$ ) occur over the desert areas such as Sahara, Arabia, Iran, North Tibet, etc. and over regions of high topography such as the Rocky Mountains 
in the Western United States, Central Mexico, Himalayan Mountains, plateaux of Tibet and Central Asia, Highlands of Ethiopia, etc. The areas of highest water vapor content are found over the equatorial regions of South America, Eastern and Western Pacific, the Indian Ocean, and equatorial West Africa. The region of lowest precipitable water (less than $0.5 \mathrm{~g} \mathrm{~cm}^{-2}$ ) is shown over the Arctic. It is interesting to note that a relative low humidity condition appears every year over the area in the Eastern Atlantic.

With regard to the year to year changes in the $\bar{W}$-field, the following points should be noted:

(a) The area enclosed by the isoline of $0.5 \mathrm{gm}$ $\mathrm{cm}^{-2}$ in the polar region varies from year to year,

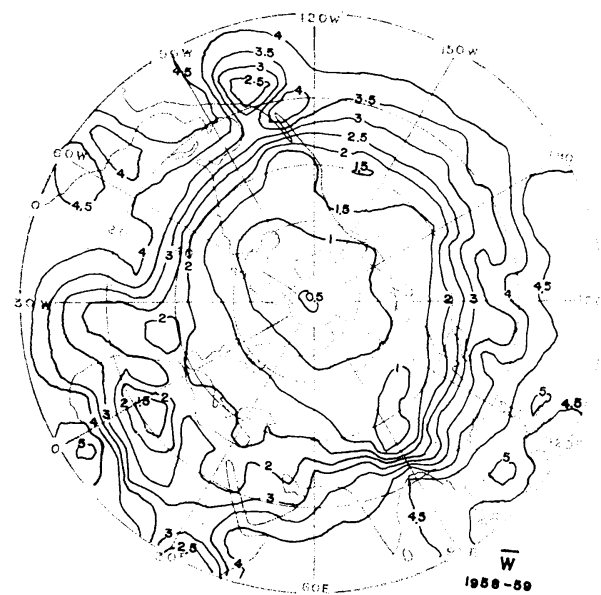

Fig. 1a The average of the vertically integrated values of specific humidity (precipitable water) $\bar{w}$, in gm per $\mathrm{cm}^{2}$ for the period May 1958-April 1959. Isoline spacing 0.5 $\mathrm{gm} \mathrm{cm}^{-2}$.

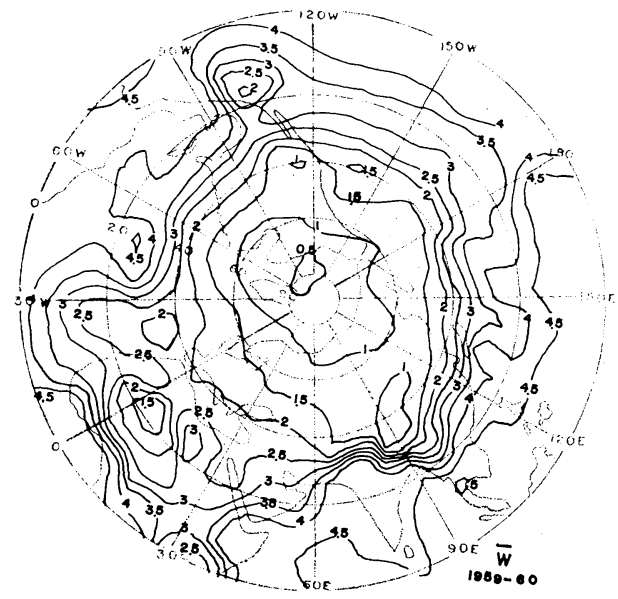

Fig. 1b Similar to Fig. 1a but for the period May 1959-April 1960.

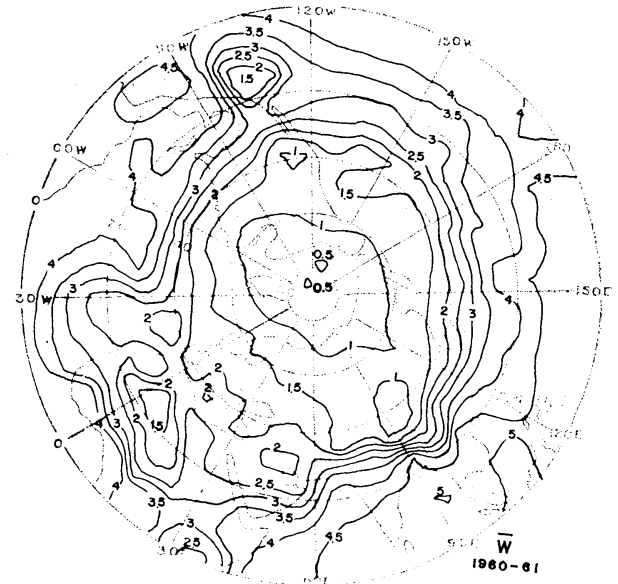

Fig. 1c Similar to Fig. 1a but for the period May 1960-April 1961.

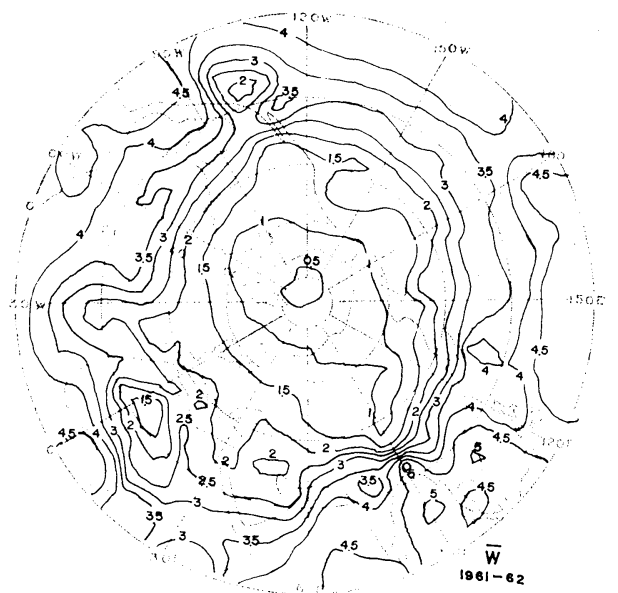

Fig. 1d Similar to Fig. 1a but for the period May 1961-April 1962.

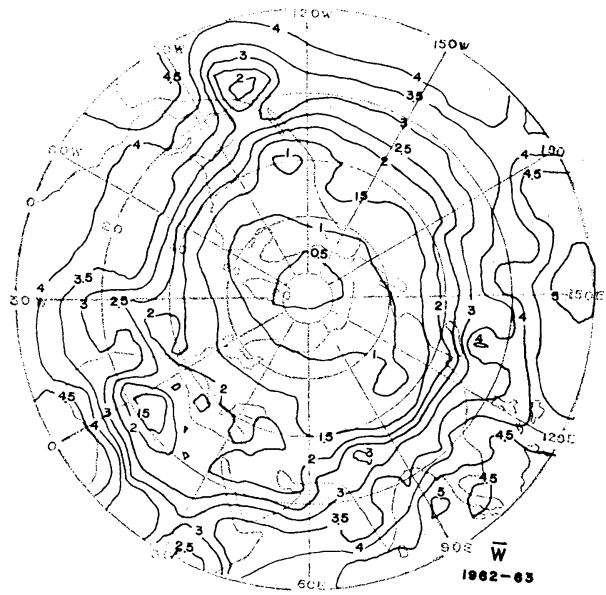

Fig. 1e Similar to Fig. 1a but for the period May 1962-April 1963. 
Table 1 Total water content in vapor form in the northern hemispheric atmosphere

\begin{tabular}{cccccc}
\hline Year & \multicolumn{1}{c}{1} & \multicolumn{1}{c}{2} & 3 & 4 & 5 \\
\hline Water content $\left(10^{15} \mathrm{~kg}\right)$ & 6.5996 & 6.5163 & 6.2854 & 6.1531 & 6.1996 \\
Hemispheric mean $\left(\mathrm{g} \mathrm{m} \mathrm{cm}^{-2}\right)$ & 2.581 & 2.555 & 2.465 & 2.315 & 2.425 \\
\hline
\end{tabular}

with largest area in year 5 and smallest in year 1.

(b) The $1.0 \mathrm{gm} \mathrm{cm}^{-2}$ isoline has an oval shape with a large part of the line circling approximately around the latitude of $60^{\circ} \mathrm{N}$. The portion of the curve, which extends to about $70^{\circ} \mathrm{N}$ over Jan Mayer and northeast of Iceland, and the portion which dips south of $60^{\circ} \mathrm{N}$ over eastern Canada and Hudson Bay do not shift their locations much from year to year. However, the portion which elongates south of $60^{\circ} \mathrm{N}$ over eastern Siberia and the Bering Sea, does change greatly within the five-year period. It penetrates south close to $40^{\circ} \mathrm{N}$ in year 5 and beyond $40^{\circ} \mathrm{N}$ in year 4 , and reaches the northern boundary of China through Mongolia (see Figures $1 \mathrm{~d}$ and 1e).

(c) Over the equatorial belt, the regions of India and southeast Asia always show abundant precipitable water with year 3 having the largest area covered by $5 \mathrm{gm} \mathrm{cm}^{-2}$ isoline. The west coast of North Africa has its maximum value of $\bar{W}$ appeared in year 1 . During year 5 (see Fig. 1e), a maximum value of $5.3 \mathrm{gm} \mathrm{cm}^{-2}$ appears in the Western Pacific.

(d) In the region between $20^{\circ} \mathrm{N}$ and $60^{\circ} \mathrm{N}$, several low humidity centers can be seen clearly in the maps. They are localized at central part of North Africa, eastern portion of the Pacific Ocean (close to Mexico), the Rocky Mountains and Sinking and Mongolia. These dry areas are persistent from year to year, although their dry conditions do vary during the five year period.

\subsubsection{Hemispherical water vapor content}

The total water content in the vapor form over the entire northern hemisphere is about $6.35 \times$ $10^{15} \mathrm{kgm}$ (or about $2.5 \mathrm{gm} \mathrm{cm}^{-2}$ ). The atmosphere keeps this amount of water fairly constant on an annual basis. The year to year changes are estimated about $3.1 \%$ less in Year 4 and about $3.9 \%$ more in Year 1, when compared with five-year mean value (see Table 1).

\subsubsection{Latitudinal distribution of the mean zonal precipitable water}

Fig. 2 shows the meridional profile of the mean zonal precipitable water content of the atmosphere $[\bar{W}]$. It is seen that $[\bar{W}]$ decreases monatonically from the equator to the pole. The

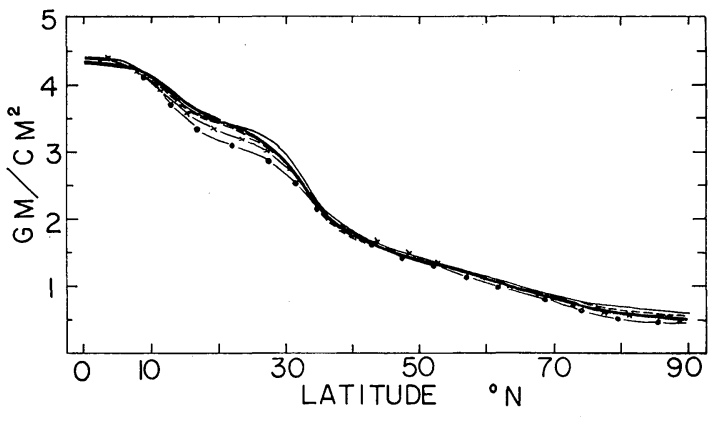

Fig. 2 Meridional profile of the annual mean zonal precipitable water $[\bar{w}]$.

rate of decrease is small in the equatorial belt, $0-5^{\circ} \mathrm{N}$, but very large in the region from about $5^{\circ} \mathrm{N}$ up to about $20^{\circ} \mathrm{N}$. From $20^{\circ} \mathrm{N}$ to about $30^{\circ} \mathrm{N}$ the slope becomes flat, but between about $30^{\circ} \mathrm{N}$ and $40^{\circ} \mathrm{N}$, the gradient is again large. In the region north of about $40^{\circ}$ up to the pole, the slope of $[\bar{W}]$ curve is fairly constant. The variations of $[\bar{W}]$ from year to year are slight.

\subsection{Variations in zonal flux \\ 4.2.1 $\bar{Q}_{\lambda}$-maps}

Figs. 3a-3e present the analysis of the vertically integrated mean zonal transport of water vapor. Isolines are drawn for every $5 \times 10^{2} \mathrm{gm} \mathrm{cm}-1$ $\mathrm{sec}^{-1}$ value. Large positive (west-to-east) centers of zonal transport are found in midlatitudes, where westerly winds are predominant, especially over the North Pacific and North Atlantic Oceans. Large negative (east-to-west) centers are found in the tropical regions where strong, persistent easterly winds prevail. The interannual variations are summarized in Table 2. Besides, some other features with regard to the year-to-year variations of the zonal flux are noted below.

(a) Two small negative centers of zonal transport (the area enclosed by a zero-isoline) are found along the souther fringes of the Arctic region, one over Western Alaska and the other over the Arctic Archipelago of Canada and over portions of Greenland. These small negative centers vary greatly from year-to-year. They appear clearly in Year 1 and 3, link together in Year 2, and shrink to a trace during the last two years. 
(b) Along the equatorial belt, easterly flow appears everywhere except over the areas around India where westerly transport occurs. This westto-east moisture flux covers the regions of the Indian Continent, Arabian Sea, Bay of Bengal, and Ceylon. Its intensity is the strongest in Year 4 , but weakest in Year 1. The pattern of the flow contains a clear maximum center in Year 3, 4 and 5, but splits into several small ones in Year 1 and becomes shapeless in Year 2.

(c) The low moisture flux condition over the North Africa is seen clearly on the maps. The changes of the flow intensity is slight from year to year. Relative larger east-to-west transports appear in Year 1, and there happens a center

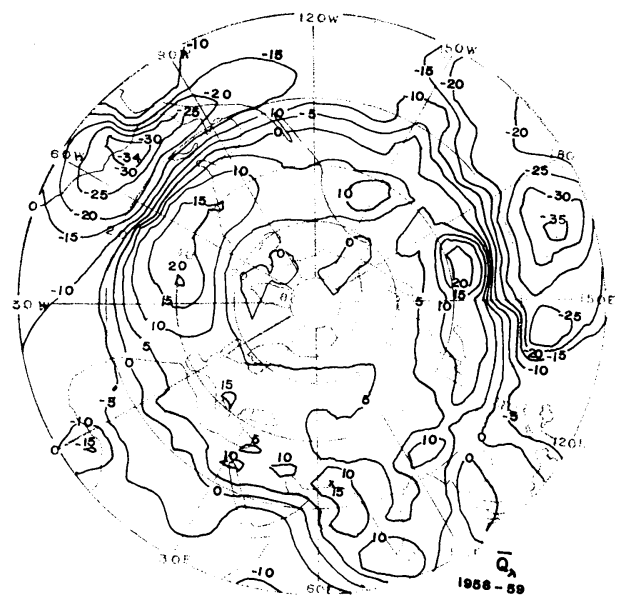

Fig. 3a Time average of the vertically integrated zonal transport of water vapor, $\bar{Q}_{\lambda}$, in $10^{2}$ $\mathrm{gm} \mathrm{cm}^{-1} \mathrm{sec}^{-1}$ for the period May 1958April 1959. Isoline spacing $5 \times 10^{2} \mathrm{gm}$ $\mathrm{cm}^{-1} \mathrm{sec}^{-1}$.

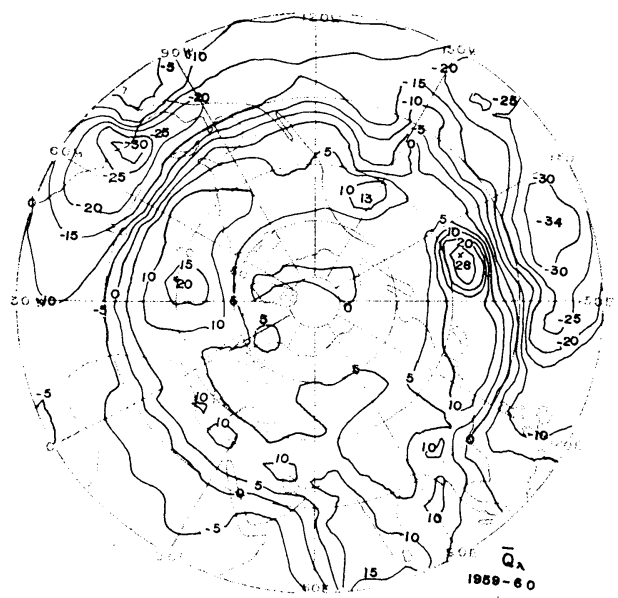

Fig. 3b Similar to Fig. 3a but for the period May 1959-April 1960.

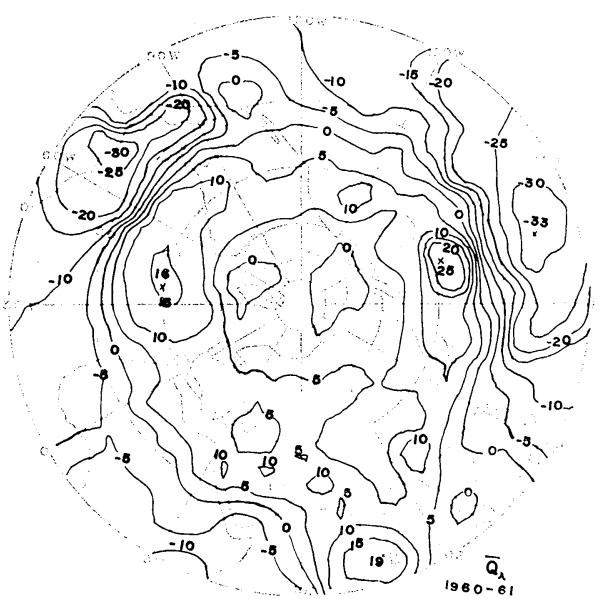

Fig. 3c Similar to Fig. 3a but for the period May 1960-April 1961.

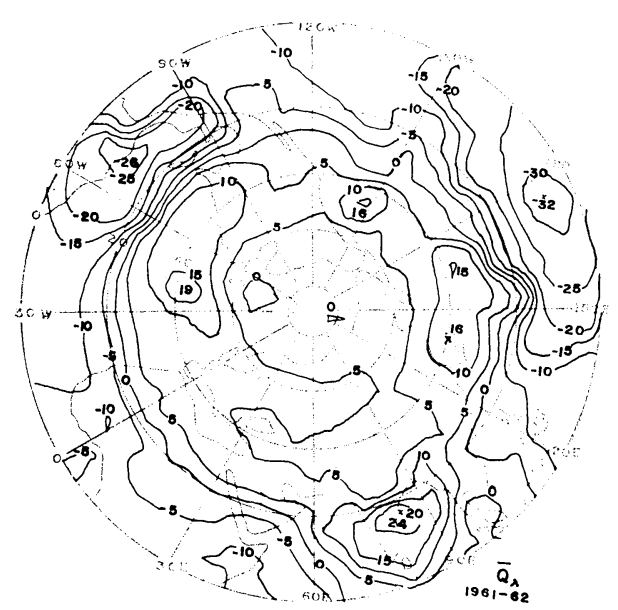

Fig. 3d Similar to Fig. 3a but for the period May 1961-April 1962.

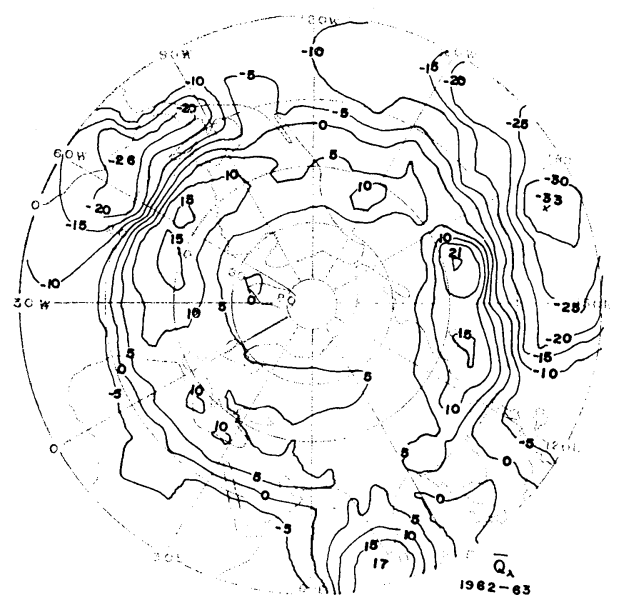

Fig. 3e Similar to Fig. 3a but for the period May 1962-April 1963. 
Table 2 Location and intensity (in $10^{2} \mathrm{gm}^{-1} \mathrm{sec}^{-1}$ ) of large $\mathrm{E}-\mathrm{W}$ transport centers

\begin{tabular}{|c|c|c|c|c|}
\hline \multirow{2}{*}{ Year } & \multicolumn{2}{|c|}{ Positive center (west-to-east) } & \multicolumn{2}{|c|}{ Negative center (east-to-west) } \\
\hline & 1 & 2 & 1 & 2 \\
\hline 1 & $\begin{array}{c}40^{\circ} \mathrm{N}, 40^{\circ} \mathrm{W} \\
20.4\end{array}$ & $\begin{array}{c}36^{\circ} \mathrm{N}, 167^{\circ} \mathrm{E} \\
22.6\end{array}$ & $\begin{array}{c}10^{\circ} \mathrm{N}, 71^{\circ} \mathrm{W} \\
-34.2\end{array}$ & $\begin{array}{c}9^{\circ} \mathrm{N}, 166^{\circ} \mathrm{E} \\
-36.1\end{array}$ \\
\hline 2 & $\begin{array}{c}39.5^{\circ} \mathrm{N}, 39.5^{\circ} \mathrm{W} \\
19.8\end{array}$ & $\begin{array}{c}35^{\circ} \mathrm{N}, 166^{\circ} \mathrm{E} \\
27.6\end{array}$ & $\begin{array}{c}10^{\circ} \mathrm{N}, 60^{\circ} \mathrm{W} \\
-32.9\end{array}$ & $\begin{array}{c}5^{\circ} \mathrm{N}, 165^{\circ} \mathrm{E} \\
-34.0\end{array}$ \\
\hline 3 & $\begin{array}{c}39^{\circ} \mathrm{N}, 36^{\circ} \mathrm{W} \\
16.3\end{array}$ & $\begin{array}{c}38^{\circ} \mathrm{N}, 166^{\circ} \mathrm{E} \\
24.6\end{array}$ & $\begin{array}{c}10^{\circ} \mathrm{N}, 71^{\circ} \mathrm{W} \\
-29.8\end{array}$ & $\begin{array}{c}9.5^{\circ} \mathrm{N}, 166^{\circ} \mathrm{E} \\
-32.5\end{array}$ \\
\hline 4 & $\begin{array}{c}41.5^{\circ} \mathrm{N}, 42^{\circ} \mathrm{W} \\
18.5\end{array}$ & $\begin{array}{c}38^{\circ} \mathrm{N}, 140^{\circ} \mathrm{E} \\
15.6\end{array}$ & $\begin{array}{c}9.7^{\circ} \mathrm{N}, 70.5^{\circ} \mathrm{W} \\
-22.6\end{array}$ & $\begin{array}{c}6^{\circ} \mathrm{N}, 176^{\circ} \mathrm{E} \\
-32.3\end{array}$ \\
\hline 5 & $\begin{array}{c}37^{\circ} \mathrm{V}, 42^{\circ} \mathrm{W} \\
16.2\end{array}$ & $\begin{array}{c}36^{\circ} \mathrm{N}, 167^{\circ} \mathrm{E} \\
20.6\end{array}$ & $\begin{array}{c}10^{\circ} \mathrm{N}, 70^{\circ} \mathrm{W} \\
-25.5\end{array}$ & $\begin{array}{c}8^{\circ} \mathrm{N}, 172.5^{\circ} \mathrm{E} \\
-33.2\end{array}$ \\
\hline
\end{tabular}

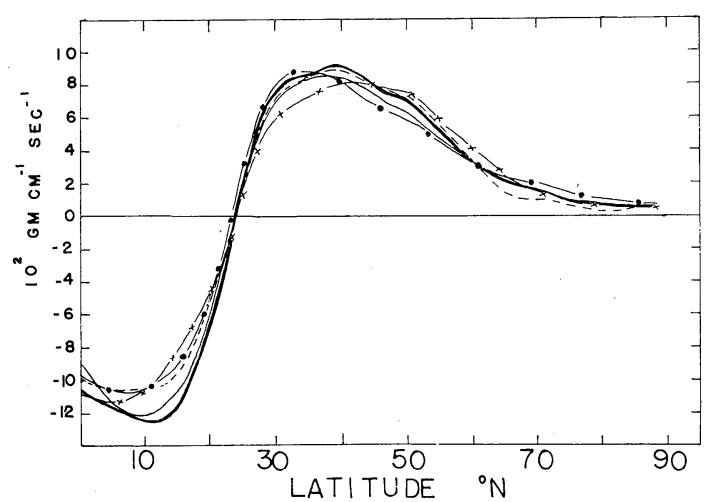

Fig. 4 Meridional distribution of the annual mean zonal flux of water vapor in the atmosphere. The heavy solid curve represents the year 1 profile, the thin curve year 2, dashed year 3 , dashed-cross year 4, and the dashed-dotted the year 5 profile.

with maximum value of about $-1,500 \mathrm{gm} \mathrm{cm}^{-1}$ $\sec ^{-1}$ at the Gulf of Guinea.

(d) A series of small positive centers are scattered in the midlatitudes over Mediterranean Sea and Central North Pacific Ocean. Of these the one located at around $45^{\circ} \mathrm{N}, 150^{\circ} \mathrm{W}$ grid point exhibits comparatively stable in its intensity and the area of coverage, but those labeled 5, 10 and 15 (between about $0^{\circ}$ and $60^{\circ} \mathrm{E}$ longitude along the $40^{\circ} \mathrm{N}$ latitude circle) are changing in location and size every year, and disappeared in Year 4.

\subsection{2 $\left[\bar{Q}_{\lambda}\right]$-profiles}

Fig. 4 shows the meridional distribution of the mean zonal flux of water vapor in the atmosphere for five individual years. The eastward flow occurs north of about $24^{\circ} \mathrm{N}$, and the westward flow appears south of that latitude. The largest positive value of the flux is in the neighborhood of $38^{\circ}$ for a five year mean case with a southward displacement to $33^{\circ}$ in year 5 and northward shifting to $42^{\circ}$ in year 4 . The maximum intensity does not vary much from year to year. The largest negative value occurs at about $10^{\circ} \mathrm{N}$ for 5-year mean case, with comparatively large interannual changes both in its magnitude and peak location. However, the latitude which divides the eastern and western flow remains fairly unchanged at about $24^{\circ} \mathrm{N}$.

\subsection{Variations in meridional flux \\ 4.3.1 $\bar{Q} \phi$-maps}

The mean meridional transports of water vapor integrated along the vertical are shown in Figs. $5 \mathrm{a}-5 \mathrm{e}$. Isolines are drawn for every $2 \times 10^{2} \mathrm{gm}$ $\mathrm{cm}^{-1} \mathrm{sec}^{-1}$. Large centers of northward (positive) flow and southward (negative) flow occur alternatively with small cells scattered throughout the northern hemisphere. Interannual variations of this field are larger when compared with $\bar{Q} \lambda$ field. Year to year differences in those relatively large centers are tabulated in Table 3. By-andlarge the locations of these large centers do not vary, with few exceptions, more than two degrees, and show their permanent features. However, the intensity does have substantial change, ranging from several percent up to a factor of two. Additional changes of $\bar{Q} \phi$ are noted below.

(a) The meridional transport of water vapor is more complex than the field of zonal transport. Large southward transport occur generally over low latitudes below about $20^{\circ} \mathrm{N}$ except over 
Eastern North Africa where the north-to-south flux extends to about $40^{\circ} \mathrm{N}$ latitude. For this part of the world the flow pattern differs greatly from one year to the next.

(b) Around the Arctic regions there are northward and southward transports. A transpolar zero-line with southward flow within the line appears clearly in Year 1 and 3, but not very clear in Year 5. This isoline breaks in Year 2 and 4 near the pole.

(c) Over Mongolia and Sinkiang, there exists a southward flux with largest center value of about $230 \mathrm{gm} \mathrm{cm}^{-1} \mathrm{sec}^{-1}$ in Year 5. During Year 2, the 0-isoline connects with the transpolar one at the grid point located $60^{\circ} \mathrm{N}$ latitude and

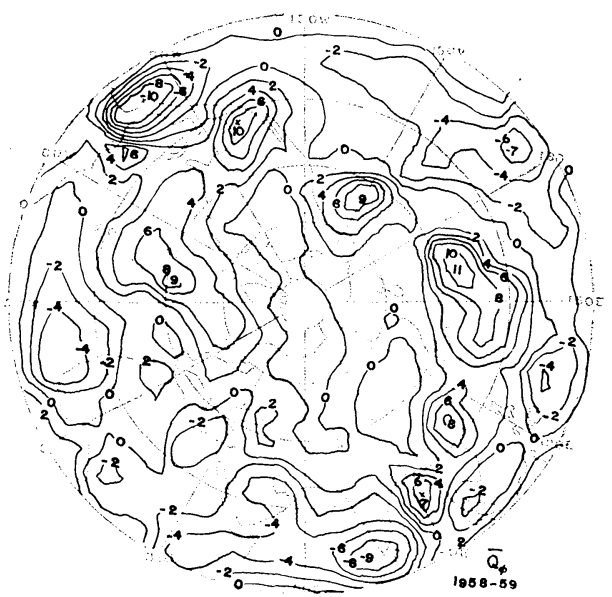

Fig. 5a Time average of the vertically integrated meridional transport of water vapor, $\bar{Q} \phi$, in $10^{2}$ grams per centimeter per second for the period May 1958-April 1959. Isoline spacing $2 \times 10^{2} \mathrm{gm} \mathrm{cm}^{-1} \mathrm{sec}^{-1}$.

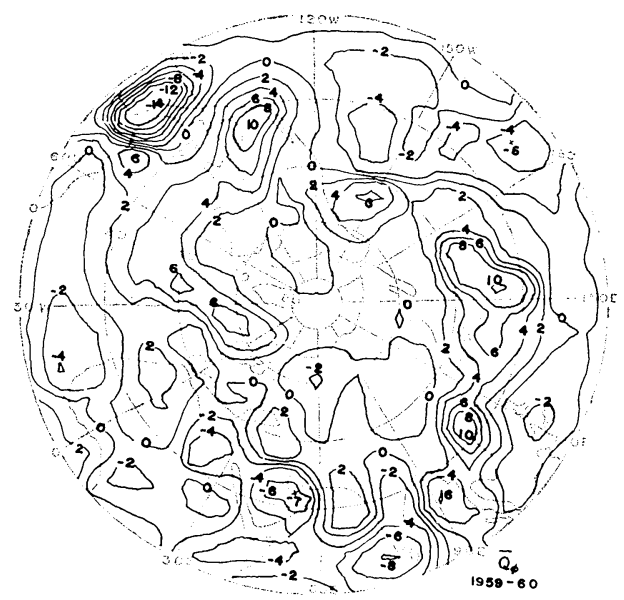

Fig. $5 \mathrm{~b}$ Similar to $5 \mathrm{a}$ but for the period May 1959-April 1960.

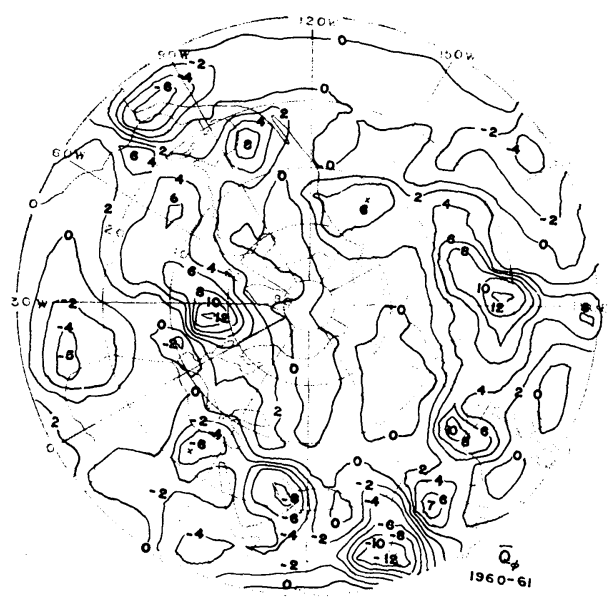

Fig. 5c Similar to 5a but for the period May 1960-April 1961.

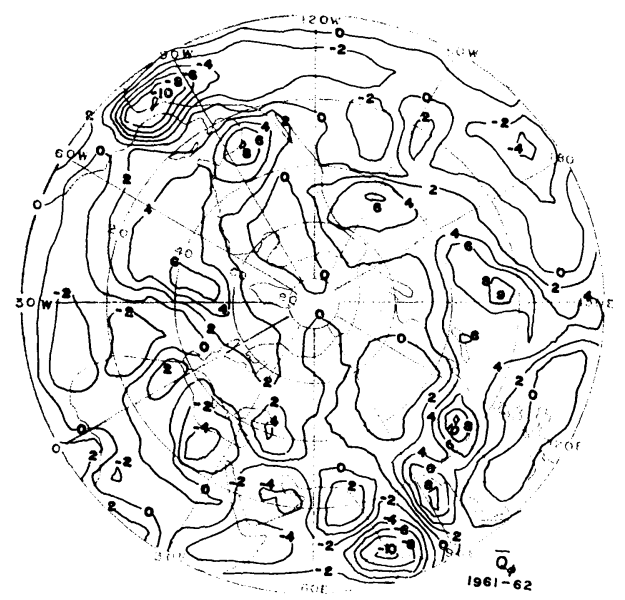

Fig. 5d Similar to 5a but for the period May 1961-April 1962.

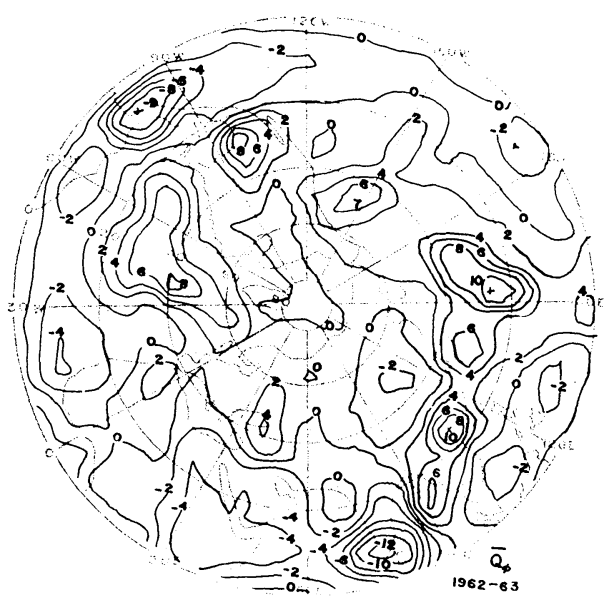

Fig. 5e Similar to 5a but for the period May 1962-April 1963. 
Table 3 Location and Strength (in $10^{2} \mathrm{gm} \mathrm{cm}^{-1} \mathrm{sec}^{-1}$ ) of Large N-S transport centers

\begin{tabular}{|c|c|c|c|c|c|c|c|c|c|c|c|}
\hline \multirow{2}{*}{ Year } & \multicolumn{6}{|c|}{ Positive center (South-to-North) } & \multicolumn{5}{|c|}{ Negative center (North-to-south) } \\
\hline & 1 & 2 & 3 & 4 & 5 & 6 & 1 & 2 & 3 & 4 & 5 \\
\hline 1 & $\begin{array}{c}40^{\circ} \mathrm{N}, \\
30^{\circ} \mathrm{W} \\
8.9\end{array}$ & $\begin{array}{c}22.5^{\circ} \mathrm{N} \\
100^{\circ} \mathrm{W} \\
9.5\end{array}$ & $\begin{array}{c}35^{\circ} \mathrm{N} \\
148^{\circ} \mathrm{W} \\
9.4\end{array}$ & $\begin{array}{c}32^{\circ} \mathrm{N} \\
164^{\circ} \mathrm{E} \\
10.5\end{array}$ & $\begin{array}{l}25.5^{\circ} \mathrm{N} \\
111.5^{\circ} \mathrm{E} \\
8.6\end{array}$ & $\begin{array}{c}14^{\circ} \mathrm{N}, \\
92^{\circ} \mathrm{E} \\
7.4\end{array}$ & $\begin{array}{r}6^{\circ} \mathrm{N}, \\
82.5^{\circ} \mathrm{W} \\
-10.0\end{array}$ & $\begin{array}{r}5^{\circ} \mathrm{N} \\
173^{\circ} \mathrm{W} \\
-7.4\end{array}$ & $\begin{array}{c}5.5^{\circ} \mathrm{N} \\
73^{\circ} \mathrm{E} \\
-9.4\end{array}$ & $\begin{array}{l}23^{\circ} \mathrm{N} \\
50^{\circ} \mathrm{E} \\
\quad-4.0\end{array}$ & $\begin{array}{l}10^{\circ} \mathrm{N}, \\
\mathrm{I}^{\circ} \mathrm{W} \\
-4.5\end{array}$ \\
\hline 2 & $\begin{array}{c}40^{\circ} \mathrm{N} \\
40^{\circ} \mathrm{W} \\
6.0\end{array}$ & $\begin{array}{l}23^{\circ} \mathrm{N} \\
98^{\circ} \mathrm{W} \\
10.3\end{array}$ & $\begin{array}{c}44^{\circ} \mathrm{N} \\
147^{\circ} \mathrm{W} \\
6.0\end{array}$ & $\begin{array}{c}26^{\circ} \mathrm{N}, \\
166^{\circ} \mathrm{E} \\
10.3\end{array}$ & $\begin{array}{l}23.5^{\circ} \mathrm{N} \\
109^{\circ} \mathrm{E} \\
10.2\end{array}$ & $\begin{array}{l}14^{\circ} \mathrm{N}, \\
92.5^{\circ} \mathrm{E} \\
6.0\end{array}$ & $\begin{array}{c}5^{\circ} \mathrm{N} \\
80^{\circ} \mathrm{W} \\
-13.8\end{array}$ & $\begin{array}{r}6^{\circ} \mathrm{N} \\
171^{\circ} \mathrm{W} \\
-6.7\end{array}$ & $\begin{array}{c}6^{\circ} \mathrm{N} \\
78^{\circ} \mathrm{E} \\
-8.1\end{array}$ & $\begin{array}{l}24^{\circ} \mathrm{N} \\
53^{\circ} \mathrm{E} \\
\quad-6.7\end{array}$ & $\begin{array}{l}10^{\circ} \mathrm{N} \\
20^{\circ} \mathrm{W} \\
\quad-4.0\end{array}$ \\
\hline 3 & $\begin{array}{l}52^{\circ} \mathrm{N} \\
24^{\circ} \mathrm{W} \\
12.7\end{array}$ & $\mid \begin{array}{c}25.5^{\circ} \mathrm{N} \\
98^{\circ} \mathrm{W} \\
7.7\end{array}$ & $\begin{array}{c}45^{\circ} \mathrm{N} \\
148^{\circ} \mathrm{W} \\
6.0\end{array}$ & $\begin{array}{c}24^{\circ} \mathrm{N} \\
166^{\circ} \mathrm{E} \\
12.3\end{array}$ & $\begin{array}{c}26^{\circ} \mathrm{N} \\
110^{\circ} \mathrm{E} \\
9.9\end{array}$ & $\mid \begin{array}{c}10.5^{\circ} \mathrm{N} \\
91^{\circ} \mathrm{E} \\
7.4\end{array}$ & $\begin{array}{r}6^{\circ} \mathrm{N} \\
81^{\circ} \mathrm{W} \\
-6.6\end{array}$ & $\begin{array}{r}4^{\circ} \mathrm{N} \\
173^{\circ} \mathrm{W} \\
-4.0\end{array}$ & $\begin{array}{c}6.5^{\circ} \mathrm{N} \\
78^{\circ} \mathrm{E} \\
-11.9\end{array}$ & $\begin{array}{l}24^{\circ} \mathrm{N} \\
53^{\circ} \mathrm{E} \\
\quad-8.3\end{array}$ & $\begin{array}{l}10^{\circ} \mathrm{N} \\
16^{\circ} \mathrm{W} \\
-5.0\end{array}$ \\
\hline 4 & $\begin{array}{c}45^{\circ} \mathrm{N} \\
40^{\circ} \mathrm{W} \\
6.0\end{array}$ & $\begin{array}{l}27^{\circ} \mathrm{N}, \\
97^{\circ} \mathrm{W} \\
8.5\end{array}$ & $\begin{array}{c}44^{\circ} \mathrm{N} \\
148^{\circ} \mathrm{W} \\
4.2\end{array}$ & $\begin{array}{c}24^{\circ} \mathrm{N}, \\
112^{\circ} \mathrm{E} \\
8.8\end{array}$ & $\begin{array}{c}26^{\circ} \mathrm{N} \\
1665 \mathrm{E} \\
10.6\end{array}$ & $\begin{array}{c}12^{\circ} \mathrm{N} \\
92.5^{\circ} \mathrm{E} \\
8.6\end{array}$ & $\begin{array}{c}7^{\circ} \mathrm{N}, \\
82^{\circ} \mathrm{W} \\
-10.2\end{array}$ & $\begin{array}{r}4^{\circ} \mathrm{N} \\
173^{\circ} \mathrm{W} \\
-4.0\end{array}$ & $\begin{array}{c}6^{\circ} \mathrm{N} \\
76^{\circ} \mathrm{E} \\
-10.3\end{array}$ & $\begin{array}{l}22^{\circ} \mathrm{N}, \\
52^{\circ} \mathrm{E} \\
\quad-4.0\end{array}$ & $\begin{array}{l}10^{\circ} \mathrm{N} \\
18^{\circ} \mathrm{W} \\
-3.3\end{array}$ \\
\hline 5 & $\begin{array}{l}40^{\circ} \mathrm{N}, \\
39.5^{\circ} \mathrm{W} \\
8.8\end{array}$ & $\begin{array}{l}26^{\circ} \mathrm{N} \\
98^{\circ} \mathrm{W} \\
9.1\end{array}$ & $\begin{array}{c}44^{\circ} \mathrm{N}, \\
148^{\circ} \mathrm{W} \\
6.7\end{array}$ & $\begin{array}{c}26^{\circ} \mathrm{N}, \\
159^{\circ} \mathrm{E} \\
11.2\end{array}$ & $\begin{array}{c}24^{\circ} \mathrm{N} \\
110^{\circ} \mathrm{E} \\
10.3\end{array}$ & $\begin{array}{c}14^{\circ} \mathrm{N} \\
94^{\circ} \mathrm{E} \\
6.0\end{array}$ & $\begin{array}{c}7^{\circ} \mathrm{N} \\
80^{\circ} \mathrm{W} \\
-9.2\end{array}$ & $\begin{array}{r}5^{\circ} \mathrm{N}, \\
173^{\circ} \mathrm{W} \\
-4.0\end{array}$ & $\begin{array}{c}6^{\circ} \mathrm{N} \\
77.5^{\circ} \mathbf{E} \\
-12 \cdot 4\end{array}$ & $\begin{array}{l}20^{\circ} \mathrm{N}, \\
54^{\circ} \mathrm{E} \\
\quad-4.0\end{array}$ & $\begin{array}{l}10^{\circ} \mathrm{N} \\
15^{\circ} \mathrm{W} \\
-4.1\end{array}$ \\
\hline
\end{tabular}

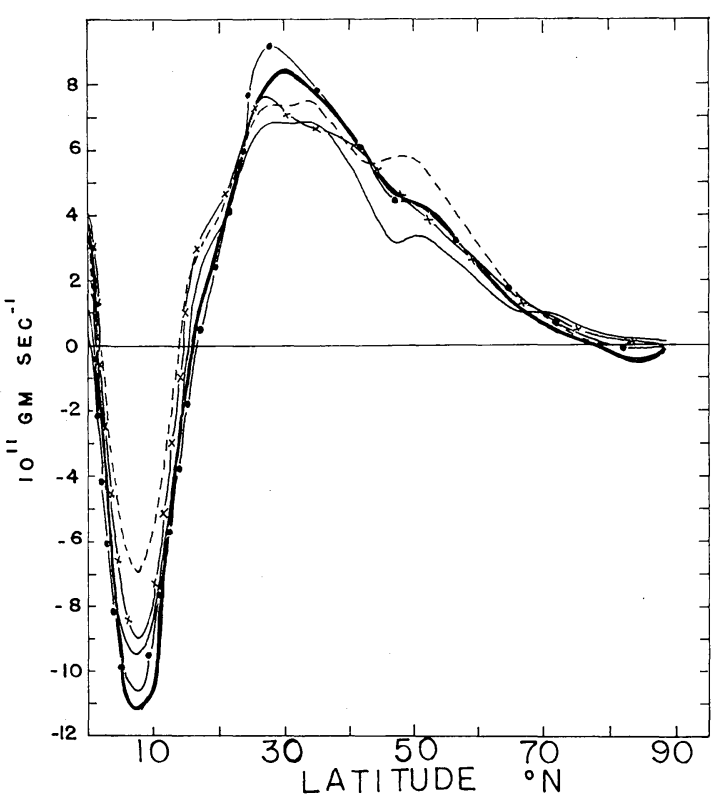

Fig. 6 Meridional distribution of the annual mean meridional flux of water vapor in the atmosphere. The heavy solid curve represents the year 1 profile, the thin curve year 2 , dashed year 3 , dashed-cross year 4 , and the dasheddotted the year 5 profile.

$90^{\circ} \mathrm{E}$ longitude.

(d) A negative center forms in the Northeast of the Hawaiian Islands in Year 2 and 4, but not in the other years.

(e) Over much of North Africa the moisture flux is southward except along the meridian of $0^{\circ}$ Greenwich where the flow is generally northward. The year-to-year variations of the flux are relatively larger over the countries of Turkey, Egypt, and Arabia than that over Morocco and Algeria. With the exception of Year 5, a negative center (not listed in Table 3) occurs each year over Libya. The center value is largest in Year 3 and smallest in Year 1.

\subsection{2 $[\bar{Q} \phi]$-profiles}

Meridional profiles of zonally averaged values $[\bar{Q} \phi]$ for five individual years are shown in Fig. 6. By-and-large a northward flux prevails over the middle latitude regions with the largest transports on the order of $8 \times 10^{11} \mathrm{gm} \mathrm{sec}^{-1}$ occuring around $30^{\circ} \mathrm{N}$, whereas a southward transport appears in the subequatorial belt, with maximum intensity on the order of $7-11 \times 10^{11} \mathrm{gm} \mathrm{sec}^{-1}$ at about $10^{\circ} \mathrm{N}$. There is a substantial amount of water vapor flowing from the southern hemisphere into the intertropical convergence zone in the northern hemisphere. The figure also shows a slight southward flux from the polar region during Year 1 and 5. The interannual variations in the maximum strength of either northward or southward flux are large.

\subsection{The standard and relative deviations}

\subsubsection{Maps of $D(\bar{W})$ and $R(\bar{W})$}

The geographical distribution of the standard deviation of the annual mean precipitable water vapor content, $D(\bar{W})$, is presented in Fig. 7a. Generally speaking, the large values of the standard deviations are in the regions between $10^{\circ} \mathrm{N}$ and $40^{\circ} \mathrm{N}$ latitudes, and the regions of small standard deviations are in the high latitudes (north of $40^{\circ} \mathrm{N}$ ) and around the equatorial belt. Pronounced centers of maximum with values larger than $0.30 \mathrm{gm} \mathrm{cm}^{-2}$ are located over Saudi 


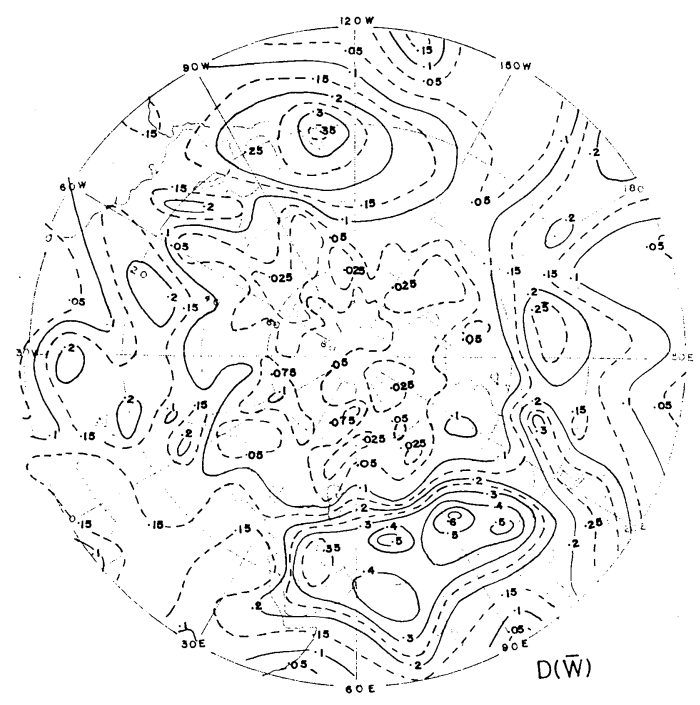

Fig. 7a Standard deviation of the annual mean precipitable water in $\mathrm{gm}$ per $\mathrm{cm}^{2}$. Isoline spacing (full curves) $0.1 \mathrm{gm} \mathrm{cm}^{-2}$.

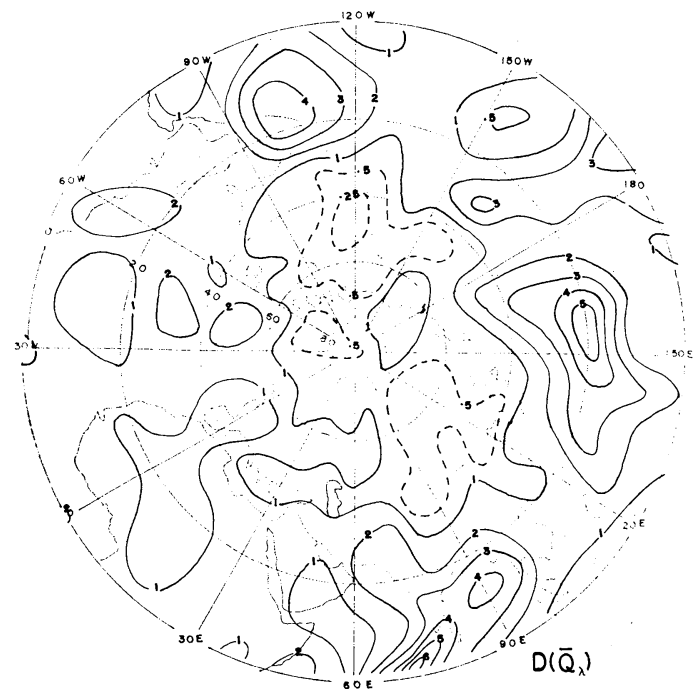

Fig. 7c Standard deviation of the annual mean zonal transport of water vapor in $10^{2} \mathrm{gm}$ $\mathrm{cm}^{-1} \mathrm{sec}^{-1}$. Isoline spacing (full curves) $100 \mathrm{gm} \mathrm{cm}^{-1} \mathrm{sec}^{-1}$.

Arabia, Arabian Sea, Pakistan, India, Tibet, Burma and the West Coast of Mexico. These centers are associated with the Tibetan Plateau and Rocky Mountains. The second large centers with values ranging from 0.25 to $0.3 \mathrm{gm} \mathrm{cm}^{-2}$ are found in the vicinity of Marcus island in the North Pacific Ocean, and along the east China Sea, Philippines Islands and Malaysia. Several small centers with $0.2 \mathrm{gm} \mathrm{cm}^{-2}$ isoline circulating

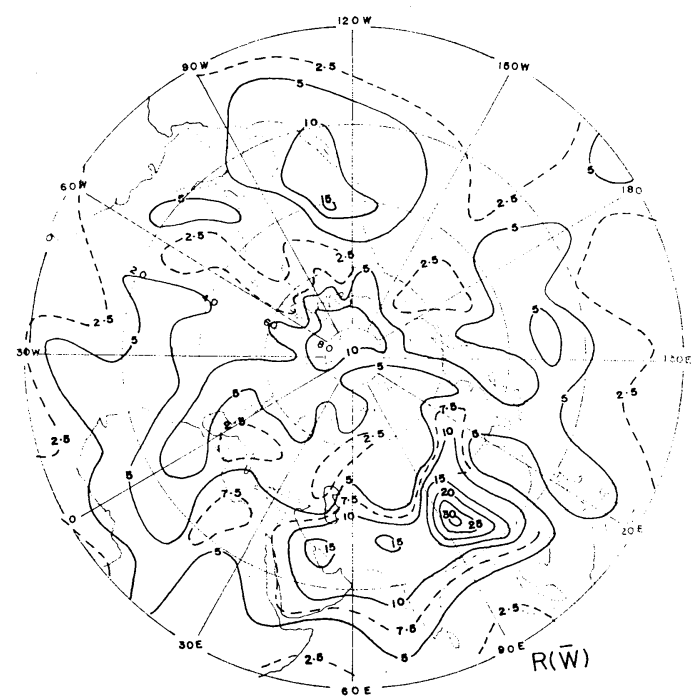

Fig. 7b Relative deviation of the annual mean precipitable water in percentage. Isoline spacing (full curves) $5 \%$.

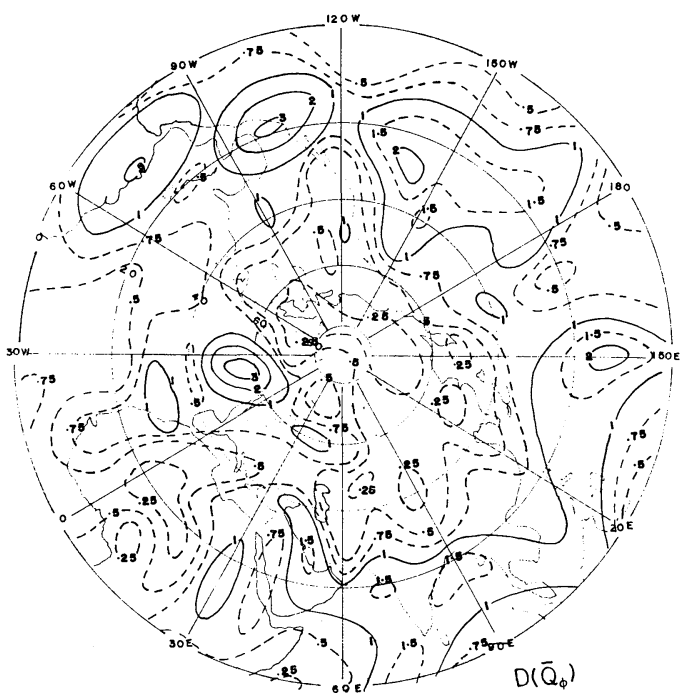

Fig. 7d Standard deviation of the annual mean meridional transport of water vapor in $10^{2}$ gm $\mathrm{cm}^{-1} \mathrm{sec}^{-1}$. Isoline spacing (full curves) $100 \mathrm{gm} \mathrm{cm}^{-1} \mathrm{sec}^{-1}$.

around them are seen in the North Atlantic Ocean, Cuba and in the North Pacific Ocean. Comparatively, over the part of the North Africa and the eastern sector of the North Pacific Ocean, the variability of $W$ is low. In the polar region the magnitude of $D(\bar{W})$ is also low.

The relative variability of $\bar{W}, R(\bar{W})$, is shown in Fig. 7b. In examining this map care must be taken to interpret its values. A large figure of 
$R(\bar{W})$ may be resulted from large $D(\bar{W})$, or small $\overline{\bar{W}}$, or their combinations. For example, the 10 percent isoline in the west half of arctic is due to lower $\overline{\bar{W}}$ and higher $D(\bar{W})$ relative to the quantities of the same variables in the east half of the arctic. A comparison between Fig. 7a and Fig. $7 \mathrm{~b}$ reveals that the pattern of $R(\bar{W})$ is consistent with that of $D(\bar{W})$. However, in some areas shifting of the center locations and isolines do occur.

\subsubsection{Map of $D\left(\bar{Q}_{\lambda}\right)$}

The hemispherical distribution of the standard deviation of the annual mean zonal transport of water vapor, $D\left(\bar{Q}_{\lambda}\right)$, is shown in Fig. 7c. The areas in the North Pacific Ocean centered around Marcus Island, the West Coast of Mexico, and the region from the Indian Ocean, extending to the Bay of Bengal have very high standard deviations. It reveals the influences of monsoon activity and the year-to-year shift of the North Pacific high. These influences are also shown in the maps of $D(\bar{W})$ and $D(\bar{Q} \phi)$ (see Figs. 7a and $7 \mathrm{~d})$. The areas in Africa, Middle East and certain points of North Atlantic and Pacific Oceans have small variabilities. Generally speaking, the variability is lower in the middle latitudes when compared with subtropics. A center of minimum stays at the north-west corner of the United States, another one encompasses northern part of China and the eastern U.S.S.R. In the polar region the area over East Siberian Sea and the Beaufort Sea in the Arctic Ocean have relatively higher variabilities than the neighborhood.

\subsubsection{Map of $D(\bar{Q} \phi)$}

The hemispherical distribution of the standard deviation of the mean meridional transport of water vapor, $D(\bar{Q} \phi)$, is shown in Fig. 7d. It is seen that the pattern of $D(\bar{Q} \phi)$ exhibits a cellular structure, which matches the maps of $\bar{Q} \phi$ (see Figs. 3a-3e).

Centers of large deviations with numerical value greater than $200 \mathrm{gm} \mathrm{cm}^{-1} \mathrm{sec}^{-1}$ are located over Mexico, west United Kingdom, Carribean Sea, the surrounding area of Guam and the eastern part of the North Pacific Ocean, while centers of minimum with value less than $25 \mathrm{gm}$ $\mathrm{cm}^{-1} \mathrm{sec}^{-1}$ are found in China, the U.S.S.R. and in the Arctic Ocean. The deviation of $\bar{Q} \phi$ in the area around India is also high with $D(\bar{Q} \phi)$ value larger than $150 \mathrm{gm} \mathrm{cm}^{-1} \mathrm{sec}^{-1}$ due to monsoon activity. It should be noted here that the estimates of $D(\bar{Q} \phi)$ are less conclusive than those of $D\left(\bar{Q}_{\lambda}\right)$, since the estimates of $\bar{Q} \phi$ are much fluctuated and many centers are observed, as shown in Table 3.

\section{Remarks}

It should be noted that the non-uniform temporal and spatial coverage of the data could greatly alter the transport maps of $\bar{Q}_{\lambda}$, and $\bar{Q}_{\phi}$ For the area where the station data is not available, the results depend much on the initial guess field. In the present work, the poor data regions are found in the equatorial portion and the central part of the north Pacific and Atlantic Oceans. The data over central part of North Africa and occasionally in India are not always satisfactory. In mid-latitudes and over much of the continents, the data are generally plenty. As mentioned earlier, our treatment to the missing data case and to the spare data sectors is to pick the values from the water vapor maps constructed for the IGY period (Peixoto and Crisi, loc. cit.) or to adopt the mean values obtained from other years as the initial guess in order to help machine in its analysis. We have compared our 5-year mean fields (not shown in this paper) with those published by Peixoto (1970) and found that they are consistent and in good agreement. We note that some differences do exist between the two reports especially around the equatorical belt. Take the 5-year mean total precipitable water vapor for example, our estimated value in the vicinity of the equator is about 5 percent less than that of his. This difference is caused by two major factors. For the first place, Peixoto integrated the humidity from $1,000 \mathrm{mb}$ to $200 \mathrm{mb}$, whereas in our case it is from the surface to the $300 \mathrm{mb}$ level. Secondly, we included more data in the southern hemisphere for improving the analysis of the tropical regions. However, the aim of this paper is not to discuss the difference between the two sets of long-term mean values, but to show the interannual variations of $\bar{W}$ and $\bar{Q}$ fields. We believe that the results presented here represent the real atmospheric condition, at least to a first approximation.

\section{Acknowledgements}

The writer wishes to express his appreciation to the late Professor V.P. Starr for guidance, to Dr. A. H. Oort for providing additional data, and to Drs. T. Maruyama and J. P. Peixoto for valuable comments. He also sincerely acknowledges the involvement and cooperation of Dr. 
R. D. Rosen. This research was supported by the Climate Dynamics Research Section, and the Atmospheric Science Section, U.S. National Science Foundation under grant no. ATM7519625.

\section{References}

Gaut, N. E., J.P. Peixoto, M.-F. Wu, and R. D. Rosen, 1976: On interannual variations of angular momentum and zonal kinetic energy in the atmosphere, Tellus, 28, 122-137.

Kubota, I., 1971: Seasonal variation in water vapor balance over the northern hemisphere and Asia. In water balance of monsoon Asia, (University of Tokyo Press), 53-73.

Oort, A. H., 1974: Year-to-year variations in the energy balance of the arctic atmosphere. $J$. Geophys. Res., 79, 1253-1260.

Peixoto, J. P. and A. R. Crisi, 1965: Hemispheric humidity conditions during the IGY., Sci. Rep. No. 6, planetary circulations projects, MIT, Cambridge, Mass., U.S.A.

Peixoto, J. P., 1970: Water vapor balance of the atmosphere from five years of hemispheric data, Nordic Hydrology, 2, 120-138.
Starr, V.P., and White, R. M., 1955: Direct measurement of the hemispheric poleward flux of water vapor. Journal of Marine Research 14, 217-225.

balance of water vapor and the hydrology of deserts. Tellus, 10, 189-194.

- - , and Livadas, G. C. 1958: On the meridional flux of water vapor in the northern hemisphere. Geof. Pura e Appl., 39, 174-185.

,-- , and Crisi, A. R. 1965: Hemispheric water balance for the IGY. Tellus, 17, 463-472.

- $\longrightarrow$, and N. E. Gaut, 1970: Momentum and zonal kinetic energy balance of the atmosphere from five years of hemispheric data. Tellus, 22, 251-274.

, and A. H. Oort, 1973: Five-year climatic trend for the northern hemisphere. Nature, 242, 310-313.

Wu, M. F., N.E. Gaut and D. T. Chang, 1974: Studies of interannual changes in momentum and zonal kinetic energy of the atmosphere for the Northern Hemisphere (Abstract). Trans. Am. Geophys. Union, 55, (4), 265.

\title{
北半球における水蒸気量とその輸送成分の年々変化
}

\author{
Mao-Fou Wu \\ Systems and Applied Sciences Corporation, アメリカ合衆国
}

大気中の水蒸気場の年々变化を研究するために, 北半球の五ヶ年の比湿と風のデータを一ケ年毎に解析した。見出 された主な点は：(1) 大気中の年平均半球全可降水量は 4\%より多く変化しないこと；(2) 緯度圈平均した東西輸送 成分は比較的変動が少いが, 緯度圏平均した南北輸送成分は, 南向き流れの最大値が 2 倍くらい, 北向き輸送の最大

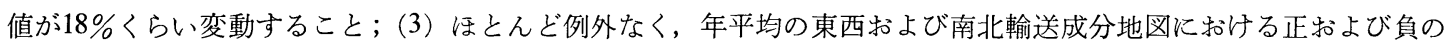
極大中心の位置は 3 緯経度より大きく変位しないが，中心の值の大きさは 5 ケ年の期間に大幅にかわること；(4) 水 蒸気量とその輸送量の変動度は, チベット高原, ロッキー山地, モンスーン活動掞よび北太平洋高気圧の年々変位に 影響されていることである。 